\title{
The effect of body size evolution and ecology on encephalization in cave bears and extant relatives
}

\author{
Kristof Veitschegger(1)
}

\begin{abstract}
Background: The evolution of larger brain volumes relative to body size in Mammalia is the subject of an extensive amount of research. Early on palaeontologists were interested in the brain of cave bears, Ursus spelaeus, and described its morphology and size. However, until now, it was not possible to compare the absolute or relative brain size in a phylogenetic context due to the lack of an established phylogeny, comparative material, and phylogenetic comparative methods. In recent years, many tools for comparing traits within phylogenies were developed and the phylogenetic position of cave bears was resolved based on nuclear as well as mtDNA.

Results: Cave bears exhibit significantly lower encephalization compared to their contemporary relatives and intraspecific brain mass variation remained rather small. Encephalization was correlated with the combined dormancy-diet score. Body size evolution was a main driver in the degree of encephalization in cave bears as it increased in a much higher pace than brain size. In Ursus spelaeus, brain and body size increase over time albeit differently paced. This rate pattern is different in the highest encephalized bear species within the dataset, Ursus malayanus. The brain size in this species increased while body size heavily decreased compared to its ancestral stage.

Conclusions: Early on in the evolution of cave bears encephalization decreased making it one of the least encephalized bear species compared to extant and extinct members of Ursidae. The results give reason to suspect that as herbivorous animals, cave bears might have exhibited a physiological buffer strategy to survive the strong seasonality of their environment. Thus, brain size was probably affected by the negative trade-off with adipose tissue as well as diet. The decrease of relative brain size in the herbivorous Ursus spelaeus is the result of a considerable increase in body size possibly in combination with environmental conditions forcing them to rest during winters.
\end{abstract}

Keywords: Physiological buffer, Dormancy, Diet, Ailuropoda, Helarctos, Melursus, Tremarctos, Ursus

\section{Background}

Cave bears, Ursus spelaeus, were a common faunal element during the Pleistocene of Europe and Asia [1]. The habitat of $U$. spelaeus was Eurasia with an east-west extension ranging from Spain to the Altai Region of Russia [1-3]. The ancestral species of $U$. spelaeus, $U$. deningeri, was even more widespread, with a habitat ranging from Spain to Siberia and even reaching the British Isles [1,3-5]. At the end of the Pleistocene, cave bears shared the same fate as most other elements of the Pleistocene megafauna and became extinct [6-8]. Their time of extinction was

Correspondence: kristof.veitschegger@pim.uzh.ch

Palaeontological Institute and Museum, University of Zurich, Karl Schmid-Strasse 4, 8006 Zürich, Switzerland proposed to be around 27.800-25.000 years BP $[9,10]$. Based on molecular data, the sister group to cave bears are brown bears, $U$. arctos, and polar bears, $U$. maritimus, together (Fig. 2). The evolutionary lineage of $U$. spelaeus split from these two bear species sometime between 2.75 to 1.2 Ma years ago [11-13]. Traditionally, cave bears were considered to be predominantly or exclusively herbivorous based on the morphology of their teeth and jaws [1, 1418]. Several studies presented isotopic as well as morphometric evidence confirming this hypothesis [2, 19-25]. However, the predominantly herbivorous diet of cave bears was questioned based on isotopic [26, 27], morphometric [28, 29], microwear [30,31], and taphonomic evidence [32]. In recent years, many of these studies were dismissed based 
on methodological errors or repeated with the result that cave bears were indeed herbivorous [2, 19, 20,33].

Cave bear brains are among the earliest ones of an extinct species to be investigated and several studies discuss different aspects of its evolution [34-42]. Many of these studies focus on the external morphology of artificial, fossil, or virtual endocasts [34, 35, 39-41]. Conflicting statements were presented concerning the overall size of the cave bear brain. Some authors suggested a small brain size compared to body size and speculated that the increase of skull size in the evolution of $U$. spelaeus outpaced brain size $[35,36]$. Others suggested high brain volumes for cave bears and an opposite scenario with brain size outpacing body size [37, 38, 42]. Many factors affect the size of brains. Brain tissue itself is known to be expensive to produce and maintain [43-45]. Absolute as well as relative brain size can be influenced by social structure [46-48], environment [48-52], sensory systems [53], evolutionary history [54-57], body size evolution [42], and different physiological as well as life history trade-offs [43, 52, 57-66].

Diet can have a profound effect on brain size as was exemplified in bats and primates [67]. Recently, it was even suggested that diet had a bigger effect on brain size than sociality in primates [68]. The diet of bears is diverse with varying amounts of plant and animal matter within and among species [2]. It ranges from hypercarnivorous in polar bears, $U$. maritimus, to folivorous in giant pandas, Ailuropoda melanoleuca $[2,69]$. Thus, diet of bears might exhibit a link to brain size.

Some bear species survive the cold seasons with extended resting periods, whereas especially tropical species are active year-round [69]. Resting periods in bears are different from deep hibernation as movement still can occur [70]. Thus, these periods are better described as dormancy in bears. Previous to dormancy, bears increase the amount of stored body fat [70]. The storage of high amounts of adipose tissue was linked to a decreased brain size [60]. Bears represent a good study object to investigate the effect of dormancy on brain size because some species are active year round whereas others increase the amount of adipose tissue annually [69].

In this study, I investigate the absolute and relative brain size of $U$. spelaeus and all extant bear species in a phylogenetic context and add remarks on $U$. deningeri. For this, I created a comprehensive brain size dataset for all extant bear species and cave bears. Additionally, I examine potential variables which could introduce energetic constraints affecting brain size evolution such as dormancy, diet, and body size. These variables were chosen because they can be reconstructed for cave bears with some measure of certainty.

\section{Methods \\ Data collection}

Altogether, I measured 412 skulls of 10 extant and extinct bear species (Table 1). U. spelaeus samples cover a time period of about 20.000 years based on radiocarbon dating [9]. Brain volume was measured using the glass bead method [71]. I used $6 \mathrm{~mm}$ diameter soda lime glass beads. The individual body mass ( $\mathrm{g}$ ) was inferred using the basicranial length (SKL) as described by van Valkenburgh: body mass $(\mathrm{kg})=2.02 * \log 10(\mathrm{SKL})-2.80$ (least squares regression) [72]. Brain volume was converted into brain mass $(\mathrm{g})$ using the specific weight of brain substance 1.036

Table 1 Results of body mass ( $\mathrm{g}$ ) and brain mass ( $\mathrm{g}$ ) estimates as well as residuals and investigated ecological scores

\begin{tabular}{|c|c|c|c|c|c|c|c|c|c|c|c|}
\hline Species & $n$ & $\begin{array}{l}\text { average body } \\
\text { mass }(\mathrm{g})\end{array}$ & $\begin{array}{l}\text { StD body } \\
\text { mass }(\mathrm{g})\end{array}$ & $\begin{array}{l}\text { average body } \\
\text { mass literature (g) }\end{array}$ & $\begin{array}{l}\text { average brain } \\
\text { mass }(\mathrm{g})\end{array}$ & $\begin{array}{l}\text { StD } \\
\text { brainmass (g) }\end{array}$ & $\begin{array}{l}\text { average } \\
\text { residuals }\end{array}$ & $\begin{array}{l}\text { StD average } \\
\text { residuals }\end{array}$ & $\begin{array}{l}\text { diet } \\
\text { score }\end{array}$ & $\begin{array}{l}\text { dormancy } \\
\text { score }\end{array}$ & $d^{*} d$ \\
\hline $\begin{array}{l}\text { Ailuropoda } \\
\text { melanoleuca }\end{array}$ & 5 & $\begin{array}{l}118^{\prime} 637 \\
\left(105^{\prime} 324-135^{\prime} 094\right)\end{array}$ & $10,748.36$ & $\begin{array}{l}97^{\prime} 500 \\
\left(70^{\prime} 000-125^{\prime} 000\right)\end{array}$ & $\begin{array}{l}281.79 \\
(238.28-331.52)\end{array}$ & 33.89 & -0.0029 & 0.0548 & 1.000 & 3.000 & 3.000 \\
\hline $\begin{array}{l}\text { Tremarctos } \\
\text { ornatus }\end{array}$ & 8 & $\begin{array}{l}80^{\prime} 918 \\
\left(64^{\prime} 223-110^{\prime} 621\right)\end{array}$ & $15,049.56$ & $\begin{array}{l}117^{\prime} 500 \\
\left(60^{\prime} 000-175,000\right)\end{array}$ & $\begin{array}{l}227.92 \\
(176.12-279.72)\end{array}$ & 31.33 & 0.0373 & 0.0320 & 1.814 & 3.000 & 5.443 \\
\hline $\begin{array}{l}\text { Ursus } \\
\text { americanus }\end{array}$ & 28 & $\begin{array}{l}117^{\prime} 116 \\
\left(83^{\prime} 885-155^{\prime} 600\right)\end{array}$ & $20,168.42$ & $\begin{array}{l}170^{\prime} 000 \\
\left(40^{\prime} 000-300^{\prime} 000\right)\end{array}$ & $\begin{array}{l}256.78 \\
(186.48-352.24)\end{array}$ & 38.39 & -0.0373 & 0.0422 & 1.884 & 1.000 & 1.884 \\
\hline $\begin{array}{l}\text { Ursus } \\
\text { arctos }\end{array}$ & 93 & $\begin{array}{l}177^{\prime} 628 \\
\left(92^{\prime} 655-320^{\prime} 042\right)\end{array}$ & $40,696.57$ & $\begin{array}{l}390^{\prime} 000 \\
\left(55^{\prime} 000-725^{\prime} 000\right)\end{array}$ & $\begin{array}{l}378.08 \\
(207.20-538.72)\end{array}$ & 61.38 & -0.0080 & 0.0464 & 1.637 & 1.000 & 1.637 \\
\hline $\begin{array}{l}\text { Ursus } \\
\text { deningeri }\end{array}$ & 1 & 254,996 & - & - & 341.88 & - & -0.1770 & - & - & - & - \\
\hline $\begin{array}{l}\text { Ursus } \\
\text { malayanus }\end{array}$ & 50 & $\begin{array}{l}82 ' 379 \\
\left(56 ' 333-108^{\prime} 841\right)\end{array}$ & $13,709.85$ & $\begin{array}{l}52^{\prime} 500 \\
\left(25^{\prime} 000-80^{\prime} 000\right)\end{array}$ & $\begin{array}{l}340.43 \\
(227.92-435.12)\end{array}$ & 47.31 & 0.2047 & 0.0403 & 2.684 & 3.000 & 8.051 \\
\hline $\begin{array}{l}\text { Ursus } \\
\text { maritimus }\end{array}$ & 82 & $\begin{array}{l}211^{\prime} 265 \\
\left(144^{\prime} 141-277^{\prime} 270\right)\end{array}$ & $33,275.87$ & $\begin{array}{l}402^{\prime} 500 \\
\left(150^{\prime} 000-655^{\prime} 000\right)\end{array}$ & $\begin{array}{l}498.80 \\
(393.68-611.24)\end{array}$ & 53.75 & 0.0525 & 0.0320 & 2.970 & 2.000 & 5.940 \\
\hline $\begin{array}{l}\text { Ursus } \\
\text { spelaeus }\end{array}$ & 99 & $\begin{array}{l}322^{\prime} 764 \\
\left(209^{\prime} 553-425^{\prime} 411\right)\end{array}$ & $57,207.28$ & $\begin{array}{l}362^{\prime} 500 \\
\left(225^{\prime} 000-500^{\prime} 000\right)\end{array}$ & $\begin{array}{l}430.10 \\
(321.16-569.80)\end{array}$ & 52.36 & -0.1550 & 0.0443 & 1.000 & 1.000 & 1.000 \\
\hline $\begin{array}{l}\text { Ursus } \\
\text { thibetanus }\end{array}$ & 29 & $\begin{array}{l}113^{\prime} 424 \\
\left(78^{\prime} 533-166^{\prime} 402\right)\end{array}$ & $21,401.65$ & $\begin{array}{l}120^{\prime} 000 \\
\left(40^{\prime} 000-200^{\prime} 000\right)\end{array}$ & $\begin{array}{l}282.58 \\
(186.48-414.40)\end{array}$ & 45.66 & 0.0155 & 0.0577 & 1.920 & 1.000 & 1.920 \\
\hline $\begin{array}{l}\text { Ursus } \\
\text { ursinus }\end{array}$ & 17 & $\begin{array}{l}147^{\prime} 081 \\
\left(124^{\prime} 439-183^{\prime} 291\right)\end{array}$ & $18,122.18$ & $\begin{array}{l}100^{\prime} 000 \\
\left(50^{\prime} 000-150^{\prime} 000\right)\end{array}$ & $\begin{array}{l}292.52 \\
(248.64-352.24)\end{array}$ & 26.04 & -0.0573 & 0.0360 & 2.606 & 3.000 & 7.818 \\
\hline
\end{tabular}


(g/cm3) [73]. The collected data is presented in Additional file 1: Table S1. To assess the validity of previously published cranial volumes of cave bears, I additionally created a data subset predicting endocranial volume based on external skull measurements for $U$. spelaeus, $U$. arctos, and $U$. malayanus [74]. Raw data for this analysis can be found in Additional file 2: Table S2.

The materials examined in this study are from the following collections: Biologiezentrum Linz (BZL), Geology School of Aristotle University Thessaloniki (AUTH), Institut für Paläontologie Wien (PIUW), Naturalis Biodiversity Center Leiden (NBC), Naturhistorisches Museum der Burgergemeinde Bern (NMBE). Naturhistorisches Museum Wien (NHM), Naturmuseum St. Gallen (NMSG), Naturmuseum Südtirol Bozen (PZO), Muséum National d'Histoire Naturelle Paris (MNHN), Museum für Naturkunde Berlin (MfN), Paleontological Institute and Museum University of Zurich (PIMUZ), and Zoological Museum University of Zurich (ZMUZH).

\section{Data analyses}

Data were log10-transformed and examined using ordinary least squares (OLS) and phylogenetic generalized least squares (PGLS) (Fig. 1, Additional file 3: Supplementary Information). I used OLS to investigate the differences in intercepts and slopes between species. Residuals from a PGLS based on brain/body mass (g) were used to investigate the differences in relative brain size. With this, the data were corrected for the effect of size. An initial investigation revealed that the data were heavily skewed by $U$. malayanus and $U$. spelaeus because of the uneven sampling (Additional file 3: Supplementary Information). All other bear species were more similar in body mass (g)/brain mass (g). This was supported by the multiple and adjusted $R^{2}$ (Additional file 3: Supplementary Information). Thus, the basis for brain/body mass (g) residuals was the slope $(0.78069)$ and intercept $(-1.50995)$ as retrieved by a PGLS excluding $U$. malayanus and $U$. spelaeus. For PGLS, the species-averaged brain mass and body mass were used. Analyses were performed in R, version 3.2.3 [75]. PGLS was executed as implemented in the packages ape and caper [76, 77]. Results from OLS regressions on all data points as well as a PGLS regression with all species are presented in the Additional file 3: Supplementary Information.

The phylogenetic relationships among Ursidae is not completely understood as there are clear discrepancies between trees based on nuclear and mitochondrial DNA (mtDNA), mirroring a complex evolutionary history with introgression and incomplete lineage sorting [78]. Complete phylogenies of Ursidae including cave bears are based on mtDNA [11, 12], therefore, I use mtDNA topology as basis for the phylogenetic analyses. The relationship between cave bears and brown bear as well as polar bear was also confirmed by nuclear DNA [79]. Recently, several new, former unrecognized species and subspecies of $U$. spelaeus were described based on morphological and genetic data [3, 80-83]. However, some of these taxa are polyphyletic $[84,85]$. Here, I include all these proposed cave bear species and subspecies in $U$. spelaeus, but exclude the well-established ancestral species $U$. deningeri [17]. $U$. deningeri is considered an anagenetic ancestor to $U$. spelaeus $[1,80]$ and thus was excluded from all analyses as it would either represent a duplication or cannot be properly placed in phylogeny. Branch lengths for phylogenetically informed analyses were retrieved from Nyakatura and Bininda-Emonds [86] and Bon [12].

Due to uneven sampling and small sample sizes in species-averaged datasets, I use non-parametric analyses. A Kruskal-Wallis test followed by a Dunn's test with Bonferroni adjustment was used on the resulting

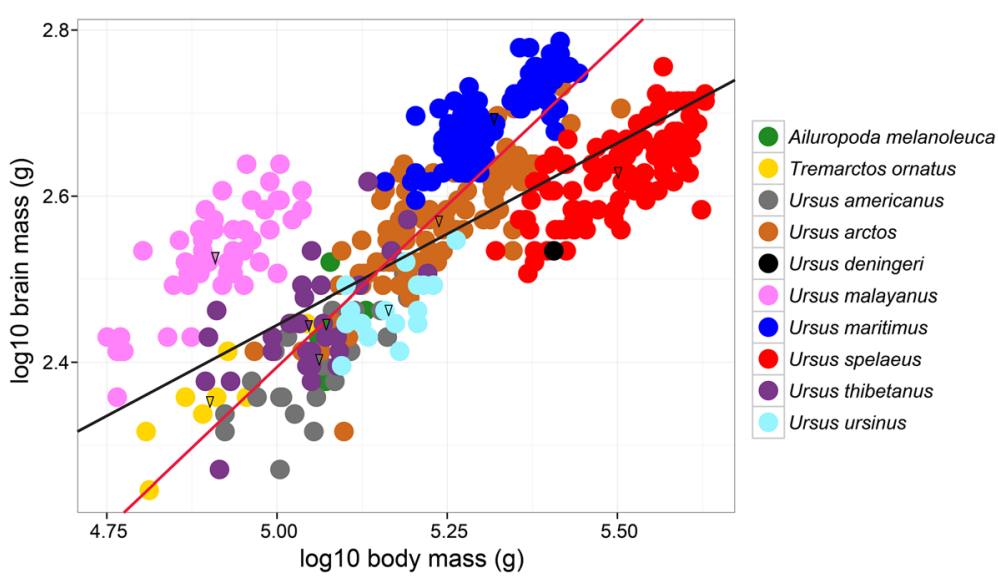

Fig. 1 Scatterplot of log10 brain mass (g) against log10 body mass (g) with a PGLS regression lines (phylogenetic generalized least squares). In black is the PGLS regression line for all data points ( $p$ value: 0.0148, slope: 0.43978 , intercept: 0.24623 , adjusted $R^{2}$ : 0.5378), in red the PGLS regression line without Ursus malayanus and Ursus spelaeus ( $p$ value: 0.0016, slope: 0.78069, intercept: -1.50995 , adjusted $R^{2}$ : 0.8606). The triangles represent the mean for each species on which PGLS was calculated 
residuals to test for significant differences. This was performed in $\mathrm{R}$, version 3.2.3 [75], using the packages pgirmess and PMCMR [87, 88]. The subset of different brain volume estimations was analysed using a Wilcoxon signed-rank test for paired samples in R, version 3.2.3. [75]. Boxplots were created in the package ggplot2 [89].

I used squared-change parsimony [90] to reconstruct ancestral stages for log 10 average body mass (g), log 10 average brain mass $(\mathrm{g})$, and averaged residuals respectively. This analysis follows a Brownian motion model of evolution [91]. The resulting ancestral character states were then used to investigate the relative mass change (in percent) from one node to the following within the tree. These analyses were performed for each variable separately in Mesquite software (version 3.01) [92].

To test for a possible effect of dormancy and diet on relative and absolute brain size, I scored each of these variables between 1 and 3: 1 represents states where a smaller brain size is expected and 3 the opposite. Dormancy was scored as 1 (dormancy), 2 (fasting periods), and 3 (no dormancy) [69]. Dietary preferences were scored using the compilation from van Heteren et al. [2]. The diet was scored between 1 (completely folivorous/low caloric diet) to 3 (completely faunivorous (high caloric diet) using the formula:

$$
\begin{aligned}
\text { Diet score }= & (\text { percent folivory/overall percent })^{*} 1 \\
& +(\text { percent frugivory/overall percent })^{*} 2 \\
& +(\text { percent faunivory/overall percent })^{*} 3
\end{aligned}
$$

The scoring enables to multiply both scores to one under the assumption that unidirectional or opposing trends show a combined effect on brain size. This is possible because the array of possible variables is constrained among three states. I performed the Kendall's tau correlation analysis in $\mathrm{R}$, version 3.2.3, using the package Kendall [93].

\section{Results}

The resulting averaged reconstructed body mass (g) and brain mass (g) with standard deviation as well as the ecological scores are given in Table 1.

The slopes of the OLS regression lines of the different bear species were not significantly different from each other. Intercepts, however, were in many cases significantly different among species (Table 2, Additional file 4: Table S3). The intercept of cave bears was not significantly different from that of $U$. americanus and $U$. ursinus.

$U$. spelaeus and $U$. deningeri have the lowest average residuals within the dataset, followed by $U$. ursinus and $U$. americanus (Fig. 2, Table 1). The highest average residuals were found in $U$. malayanus and $U$. maritimus. The Kruskal-Wallis test followed by a Dunn's test with Bonferroni adjustment revealed that the residuals of $U$. spelaeus are significantly smaller than of most other bear species, except for $U$. ursinus and A. melanoleuca (Table 3).
The biggest documented cave bear brain volume is 1.8 times bigger than the smallest. In comparison, in $U$. arctos it is 2.6 times bigger and in $U$. thibetanus 2.2 times. Polar bears, however, exhibit low variation with the biggest brain volume being 1.6 times bigger than the smallest (Table 1).

The comparison between different methods to estimate brain volumes revealed that external measurements produced results significantly different from brain volume measured directly with glass beads (Fig. 3). In $U$. spelaeus, brain volumes inferred by external measurements were significantly higher than those measured with soda lime glass beads $(n=15$, median glass beads $=410 \mathrm{ml}$, median external measurements $=480 \mathrm{ml}, \mathrm{V}=120, p$-value $=<0.0001)$. The opposite is true for $U$. arctos and $U$. malayanus. Here, brain volumes were significantly higher when measured with glass beads $(U$. arctos: $n=34$, median glass beads $=370 \mathrm{ml}$, median external measurements $=312 \mathrm{ml}$, $\mathrm{V}=66, p$-value $=<0.0001 ; U$. malayanus: $n=9$, median glass beads $=310 \mathrm{ml}$, median external measurements $=191 \mathrm{ml}, \mathrm{V}=0, p$-value $=0.0039$ ).

The ancestral stage reconstruction based on squaredchange parsimony revealed that the small relative brain size of $U$. spelaeus and $U$. ursinus represent a secondarily derived condition, as their respective ancestral stages exhibit a higher relative brain size (Fig. 2, Additional file 5: Table S4). The comparison between the relative change of body mass ( $g$ ) and brain mass ( $g$ ) shows that the evolution of a bigger body size in $U$. spelaeus outpaced brain size evolution. Both increased size compared to their ancestral stages, respectively; however, body size increased at a much higher pace. The reverse was found in $U$. maritimus, in which brain size evolution outpaced body size increase. Nonetheless, in $U$. maritimus and $U$. spelaeus brain as well as body size evolution are unidirectional towards increasing. In $U$. americanus the trend is unidirectional towards decrease. These cases contrast with the decoupling trend recorded for $U$. malayanus. In this species, the body size decreases where the brain size increases leading to the high relative brain size found in this species. At the basis of the tree, the analysis retrieved an ancestral body mass of 112,052 $\mathrm{g}$ and a brain mass of $277 \mathrm{~g}$.

Using Kendall's tau to find correlations between ecological scores and brain mass (g) revealed no significant results. Residuals were not significantly correlated with dormancy or diet scores. However, residuals were correlated with the combined score (Table 4).

\section{Discussion}

\section{Encephalization in Ursidae}

$U$. spelaeus had a significantly smaller relative brain size than most extant bear species. The brain size variation in cave bears over time, between males and females [1] as well as high altitude and lowland populations [81] did not exceed the intraspecific variation in extant $U$. americanus, 
Table 2 Results of the pairwise comparisons of slopes and intercepts among different bear species

\begin{tabular}{|c|c|c|c|c|c|c|c|c|c|}
\hline & $\begin{array}{l}\text { Ailuropoda } \\
\text { melanoleuca }\end{array}$ & $\begin{array}{l}\text { Tremarctos } \\
\text { ornatus }\end{array}$ & $\begin{array}{l}\text { Ursus } \\
\text { americanus }\end{array}$ & $\begin{array}{l}\text { Ursus } \\
\text { arctos }\end{array}$ & $\begin{array}{l}\text { Ursus } \\
\text { malayanus }\end{array}$ & $\begin{array}{l}\text { Ursus } \\
\text { maritimus }\end{array}$ & $\begin{array}{l}\text { Ursus } \\
\text { spelaeus }\end{array}$ & $\begin{array}{l}\text { Ursus } \\
\text { thibetanus }\end{array}$ & $\begin{array}{l}\text { Ursus } \\
\text { ursinus }\end{array}$ \\
\hline $\begin{array}{l}\text { Ailuropoda } \\
\text { melanoleuca }\end{array}$ & & $+/-0.0034$ & $+/-0.0366$ & $+/-0.0306$ & $+/-0.1725^{* * * * *}$ & $+/-0.1086^{* * * * *}$ & $+/-0.0596^{* * *}$ & $\begin{array}{l}+/- \\
0.0129\end{array}$ & $\begin{array}{l}+/- \\
0.0347\end{array}$ \\
\hline $\begin{array}{l}\text { Tremarctos } \\
\text { ornatus }\end{array}$ & $+/-0.4053$ & & $+/-0.0400^{* *}$ & $+/-0.0273$ & $+/-0.1691^{* * * * *}$ & $+/-0.1052^{* * * * *}$ & $+/-0.0630^{* * *}$ & $\begin{array}{l}+/- \\
0.0096\end{array}$ & $\begin{array}{l}+/- \\
0.0380^{*}\end{array}$ \\
\hline $\begin{array}{l}\text { Ursus } \\
\text { americanus }\end{array}$ & $+/-0.3957$ & $+/-0.0096$ & & $+/-0.0672^{* * * * *}$ & $+/-0.2091^{* * * * *}$ & $+/-0.1452^{* * * * *}$ & $+/-0.0230$ & $\begin{array}{l}+/- \\
0.0495^{* * * * *}\end{array}$ & $\begin{array}{l}+/- \\
0.0019\end{array}$ \\
\hline $\begin{array}{l}\text { Ursus } \\
\text { arctos }\end{array}$ & $+/-0.3362$ & $+/-0.0691$ & $+/-0.0595$ & & $+/-0.1419^{* * * * *}$ & $+/-0.0779^{* * * * *}$ & $+/-0.0903^{* * * * *}$ & $\begin{array}{l}+/- \\
0.0177\end{array}$ & $\begin{array}{l}+/- \\
0.0653^{* * * * *}\end{array}$ \\
\hline $\begin{array}{l}\text { Ursus } \\
\text { malayanus }\end{array}$ & $+/-0.3895$ & $+/-0.0158$ & $+/-0.0062$ & $+/-0.0533$ & & $+/-0.0639^{* * * * *}$ & $+/-0.2321^{* * * * *}$ & $\begin{array}{l}+/- \\
0.1596^{* * * * *}\end{array}$ & $\begin{array}{l}+/- \\
0.2072^{* * * * *}\end{array}$ \\
\hline $\begin{array}{l}\text { Ursus } \\
\text { maritimus }\end{array}$ & $+/-0.2864$ & $+/-0.1189$ & $+/-0.1093$ & $+/-0.0498$ & $+/-0.1031$ & & $+/-0.1682^{* * * * *}$ & $\begin{array}{l}+/- \\
0.0956^{* * * * *}\end{array}$ & $\begin{array}{l}+/- \\
0.1432^{* * * * *}\end{array}$ \\
\hline $\begin{array}{l}\text { Ursus } \\
\text { spelaeus }\end{array}$ & $+/-0.2161$ & $+/-0.1892$ & $+/-0.1796$ & $+/-0.1200$ & $+/-0.1734$ & $+/-0.0702$ & & $\begin{array}{l}+/- \\
0.0726^{* * * * *}\end{array}$ & $\begin{array}{l}+/- \\
0.0250\end{array}$ \\
\hline $\begin{array}{l}\text { Ursus } \\
\text { thibetanus }\end{array}$ & $+/-0.2497$ & $+/-0.1556$ & $+/-0.1460$ & $+/-0.0865$ & $+/-0.1398$ & $+/-0.0367$ & $+/-0.0335$ & & $\begin{array}{l}+/- \\
0.0476^{* * * * *}\end{array}$ \\
\hline $\begin{array}{l}\text { Ursus } \\
\text { ursinus }\end{array}$ & $+/-0.1606$ & $+/-0.2447$ & $+/-0.2351$ & $+/-0.1756$ & $+/-0.2289$ & $+/-0.1258$ & $+/-0.0555$ & $\begin{array}{l}+/- \\
0.0891\end{array}$ & \\
\hline
\end{tabular}

Significant results are marked with stars ( $p$-value: ${ }^{*}<0.5,{ }^{* *}<0.1,{ }^{* * *}<0.01,{ }^{* * * *}<0.001,{ }^{* * * * *}<0.0001$ )

Upper triangle shows intercept comparisons and lower triangle shows slope comparisons

$U$. arctos, $U$. malayanus, and $U$. thibetanus. Especially, the relative brain size of $U$. arctos and $U$. thibetanus exhibits a considerable amount of variation. The study of brain size evolution often focuses on the evolution of increased encephalization and intelligence [38, 94-99]. Animals with bigger relative brain size often show more flexibility in behaviour and are potentially more adaptable [100-104]. Nonetheless, brain tissue is expensive and producing it comes at the cost of a slower life history [43-45, 57, 64, 105]. Therefore, in some species a secondary reduction of relative or absolute brain size was described [106]. Especially, islands represent a challenging habitat for many mammals and several species exhibit a secondary decrease in encephalization $[107,108]$. Dormancy and diet, separately, were not correlated with brain size; however, the combination of both variables showed a significant effect. A possible explanation for this correlation could be that cave bears underwent a change in diet in a habitat in which they were still forced to rest during winters $[1,9]$ limiting the possibility of so called cognitive buffering [66, 109]. Under the Cognitive Buffer hypothesis, it is expected that relative brain size of mammals in highly seasonal environment increases due to the necessity of behavioural flexibility. This, however, also implies an active reaction towards the environmental change. In contrast, dormancy does not require this high level of behavioural flexibility but relies on body fat storage, which additionally has a negative trade-off with brain size $[60,66]$. This suggests that brain size in cave bears might exhibit a physiological buffering effect [66] partly constraining relative brain size. Other bear species such as $U$. arctos and $U$. americanus would also exhibit this physiological buffering effect but their food quality or life history might lessen the constraint on relative brain size.

In Ursidae, three life history variables have been demonstrated to correlate with encephalization: gestation time (negative), newborn mass (positive), and litter size (negative) [57]. In A. melanoleuca, a combination of these variable with a year-round active strategy [69] is potentially the reason why the second herbivorous species in the dataset exhibits an encephalization higher than found in cave bears. Nonetheless, the life history correlates with encephalization are not unidirectional in the giant panda. In contrast, the highest encephalized species, $U$. malayanus, shows unidirectional trends towards increased encephalization in most variables with heavy newborns, small litter size, non-resting strategy, and $68 \%$ faunivory $[2,69,110]$. Gestation time and litter size are not known for $U$. spelaeus. However, cave bears were about the same size as $U$. arctos at birth $[14,111]$, contributing to its small relative brain size. A small relative brain size can already be traced in $U$. deningeri. This ancestor of $U$. spelaeus also exhibits low encephalization and is usually considered a herbivorous species with winter resting behaviour as well [25, 112].

The effect of diet alone on brain size in Ursidae remains elusive. In other groups such as primates and bats the link is more apparent. Fruit, blood, and meat eating bats tend to be more encephalized than their insecteating relatives and in primates leaf-eaters are the least encephalized [67, 68]. Although a comparable link was proposed for Carnivora, it is hypothesized to be more 


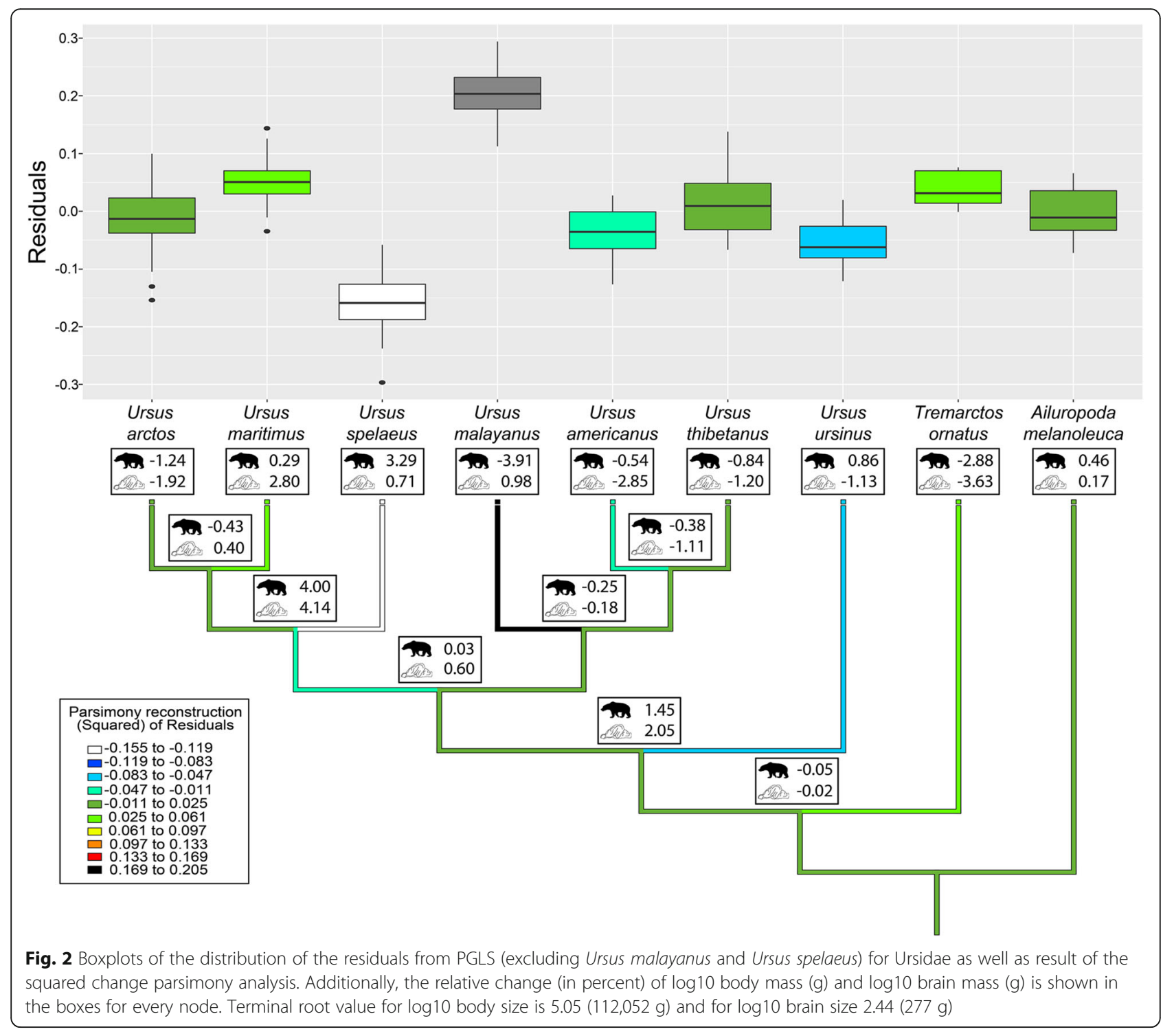

Table 3 Results of the Kruskal-Wallis rank sum test on the residuals of investigated bear species

\begin{tabular}{|c|c|c|c|c|c|c|c|c|}
\hline \multicolumn{9}{|c|}{ Kruskal-Wallis rank sum test } \\
\hline $\begin{array}{l}\mathrm{K}-\mathrm{W} \text { chi-squared: } 338.89 \\
\mathrm{df}: 8, p \text {-value: }<0.0001\end{array}$ & $\begin{array}{l}\text { Ailuropoda } \\
\text { melanoleuca }\end{array}$ & $\begin{array}{l}\text { Tremarctos } \\
\text { ornatus }\end{array}$ & $\begin{array}{l}\text { Ursus } \\
\text { americanus }\end{array}$ & $\begin{array}{l}\text { Ursus } \\
\text { arctos }\end{array}$ & $\begin{array}{l}\text { Ursus } \\
\text { malayanus }\end{array}$ & $\begin{array}{l}\text { Ursus } \\
\text { maritimus }\end{array}$ & $\begin{array}{l}\text { Ursus } \\
\text { thibetanus }\end{array}$ & $\begin{array}{l}\text { Ursus } \\
\text { ursinus }\end{array}$ \\
\hline Tremarctos ornatus & 1.0000 & - & - & - & - & - & - & - \\
\hline Ursus americanus & 1.0000 & 0.7560 & - & - & - & - & - & - \\
\hline Ursus arctos & 1.0000 & 1.0000 & 1.0000 & - & - & - & - & - \\
\hline Ursus malayanus & 0.0699 & 0.4557 & $<0.0001$ & $<0.0001$ & - & - & - & - \\
\hline Ursus maritimus & 1.0000 & 1.0000 & $<0.0001$ & $<0.0001$ & 0.0006 & - & - & - \\
\hline Ursus thibetanus & 1.0000 & 1.0000 & 0.8645 & 1.0000 & $<0.0001$ & 0.7134 & - & - \\
\hline Ursus ursinus & 1.0000 & 0.2586 & 1.0000 & 1.0000 & $<0.0001$ & $<0.0001$ & 0.2484 & - \\
\hline Ursus spelaeus & 0.1133 & $<0.0001$ & 0.0005 & $<0.0001$ & $<0.0001$ & $<0.0001$ & $<0.0001$ & 0.2602 \\
\hline
\end{tabular}




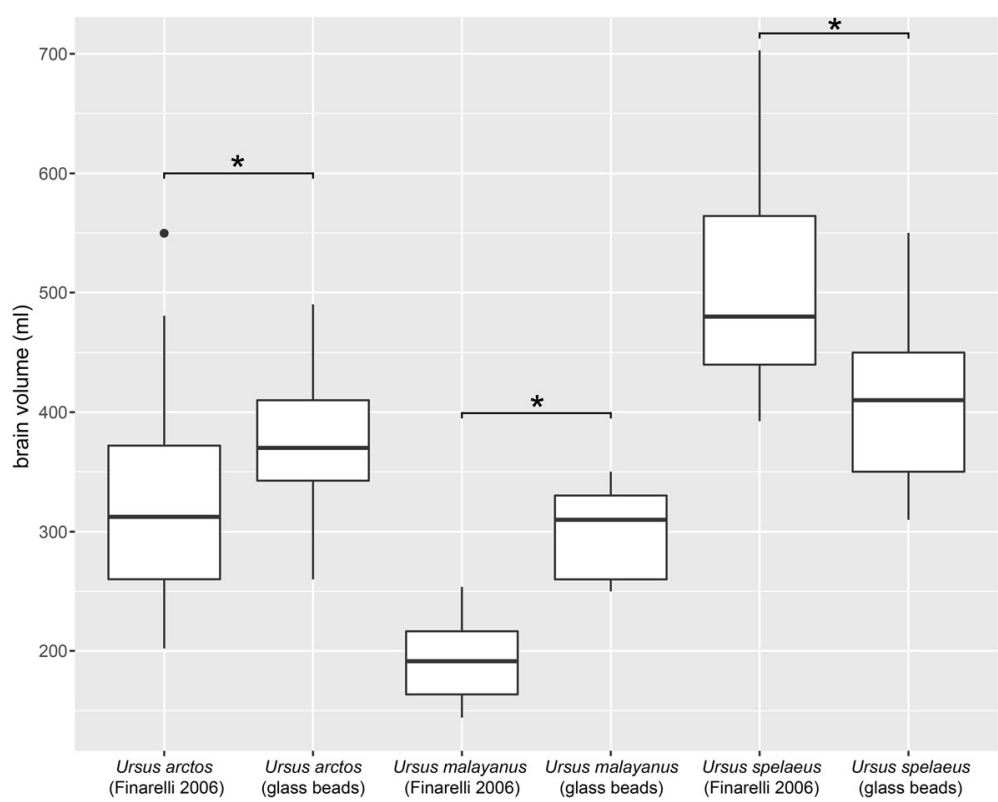

Fig. 3 Comparison between two methods for estimating brain volumes of Ursidae (asterisks mark significant differences based on a Wilcoxon signed-rank test)

associated with the process of acquiring food rather than the energetics of the diet itself $[54,67]$. The change in diet in cave bears and associated smaller relative brain size is reminiscent of the often mentioned evolutionary arms-race between Carnivora and Ungulates in which Carnivora had to be more encephalized to outsmart their (herbivorous) prey [98]. This scenario, however, was later found to be unsubstantiated [113].

Smaers et al. [42] suggested that absolute brain size in the evolution of $U$. spelaeus was outpacing body size. This pattern was based on brain size estimates obtained by external measurements [37, 38, 74]. Although external measurements can predict brain volume with a certain confidence $[74,114]$, they can also have considerable prediction error [114]. The results of this study show that external measurements overestimate the endocranial volume of $U$. spelaeus (Fig. 3). The reason for this might be the frontal bossing found in cave bears likely caused by an extension of the frontal sinuses [16, 17, 35, 36, 41]. My results show that in cave bears body size evolution outpaced brain size evolution. Thus attesting to a remark by Marinelli [36]. Smaers et al. [42] also published brain and body size variables for three other extinct bear species Arctodus simus (3 $\mathrm{Ma}-0.01 \mathrm{Ma})$, Cephalogale ursinus
(23.8 $\mathrm{Ma}-22.8 \mathrm{Ma})$, and Indarctos oregonensis (10.3 Ma - $5.3 \mathrm{Ma}$ ). With these values $C$. ursinus would be placed high above the regression line (residual: 0.33), A. simus close to the line (residual: 0.04), and I. oregonensis below the line (residual: -0.16). Fossil evidence has shown to change the results of suggested bidirectional evolution in brain size $[99,106]$. However, in ursids, the cave bear lineage represents one of the least encephalized compared to extant and most extinct relatives.

\section{On the methodology of body mass reconstruction}

I calculated the mass of every specimen individually based on skull length [72]. My body mass estimates, generally, were well within the range of known body mass distribution for each species (Table 1) [69]. However, the estimations for polar bears, $U$. maritimus, are generally small. Thus, this animal might be closer to the range of other bear species such as $U$. arctos in the scatterplot (Fig. 1). It is, nonetheless, possible that the measured skulls are from individuals from the lower range of mass distribution of this species. The opposite is true for the two smaller bear species $U$. malayanus and $U$. ursinus. $U$. malayanus potentially could have even bigger brains compared to body size than in the presented dataset. $U$. ursinus would

Table 4 Results of Kendall's tau on different scores as well as the combination of both

\begin{tabular}{|c|c|c|c|c|c|c|}
\hline & \multicolumn{2}{|c|}{ Diet score (d) } & \multicolumn{2}{|c|}{ Dormancy score (d) } & \multicolumn{2}{|l|}{$d^{*} d$} \\
\hline & tau & $p$-value & tau & $p$-value & tau & $p$-value \\
\hline Average brain mass $(\mathrm{g})$ & 0.1970 & 0.5294 & -0.1360 & 0.7285 & 0.0000 & 1.0000 \\
\hline Residuals & 0.3660 & 0.2084 & 0.3400 & 0.2976 & 0.5560 & 0.0476 \\
\hline
\end{tabular}

In bold are significant correlations 
be within the range of other extant bear species in the scatterplot (Fig. 1) such as $U$. arctos. U. spelaeus is considered to be one of the biggest carnivorans [115], with some estimates suggesting it to have surpassed the size of the polar bear or the Kodiak brown bear, $U$. a. middendorffi, by reaching a body mass of about 1'500 $\mathrm{kg}$ [1]. Based on this, the cave bear could have had an exceptionally small relative brain size. Considering the possible bias body mass estimations based on skull length had on the dataset, encephalization in Ursidae could be more even with two strong outliers, $U$. malayanus towards increased encephalization and $U$. spelaeus towards decreased one.

\section{Conclusion}

The aim of this study was to examine the encephalization in cave bears and comparing it with living and extinct members of Ursidae. U. spelaeus, and subsequently all potential species associated with this taxon, exhibit one of the lowest encephalization in Ursidae because body size increase outpaced brain size increase in its evolution. This is a trend observable early on in the cave bear lineage as is evidenced by the low encephalization of $U$. deningeri. My results stand in contrast to previous interpretations of cave bear brain evolution [42]. I showed that this study has used overestimated brain volumes due to the shape of cave bear skulls. Bear species, which do not exhibit dormancy and have a high caloric diet, showed a weak but significant correlation with bigger relative brain size. This would be in accordance with the trait-off between brain size and adipose tissue as well as studies on diet and brain size [60, 66-68]. The ecological shift towards a plant based diet alone did not affect encephalization in cave bears. However, a more general link associated with food acquirement strategy might still exist [67]. The herbivorous $U$. spelaeus has a small relative brain size possibly due to the combined effect of unequal body/brain size evolution and a seasonal environment in which dormancy was necessary for survival.

\section{Additional files}

Additional file 1:Table S1. Basicranial length, body mass estimates, brain volumes and brain mass for all examined bear skulls. (XLSX 33 kb)

Additional file 2: Table S2. Data subset of brain volume estimates based on external measurements by Finarelli [74] and glass bead method. (XLSX $12 \mathrm{~kb}$ )

Additional file 3: Supplementary Information. Results for different linear models and corresponding graphical output as well as boxplot on residuals based on PGLS with all species. (PDF $658 \mathrm{~kb}$ )

Additional file 4: Table S3. Additional results for slope and intercept pairwise comparisons. (XLSX $31 \mathrm{~kb}$ )

Additional file 5: Table S4. Node values for ancestral stage reconstructions. (XLSX $13 \mathrm{~kb}$ )

\section{Acknowledgments}

This paper is part of a doctoral thesis at the University of Zurich supervised by Marcelo R. Sánchez-Villagra, Evolutionary Morphology and Palaeobiology of Vertebrates (PIMUZ). I want to acknowledge the many institutions and people giving us access to their collections. Thus, I want to thank Björn Berning (BZL), Toni Bürgin (NMSG), Stephanie Fassl (PIUW), Christine Frischauf (PIUW), Christiane Funk (MfN), Ursula B. Göhlich (NHM), Marianne Haffner (ZMUZH), Oliver Hampe (MfN), Lars van den Hoek Ostende (NBC), Evelyn Kustatscher (PZO), Marc Nussbaumer (NMBE), Barbara Oberholzer (ZMUZH), Natasja den Ouden (NBC), Gernot Rabeder (PIUW), Thomas Schossleitner (MfN), Martin Studeny (BZL), Evangelia Tsoukala (AUTH), Géraldine Veron (MNHN) for their support. Additionally, I am grateful to Karin Isler (AIMZH) for fruitful discussions on methodology and design of this study and Marcelo R. Sánchez-Villagra (PIMUZ) for discussions and editions to the text. I also want to thank Vera Weisbecker (UQ) and two anonymous reviewers for their helpful comments, which considerably improved this study. Funding for this research was provided by the Swiss National Science Foundation (SNF) grant no. 31003A-149605 to Marcelo R. Sánchez-Villagra.

\section{Availability of data and materials}

All data generated and/or analysed during this study are included in this published article and its supplementary information files.

\section{Competing interests}

I declare no competing interests of any kind.

\section{Publisher's Note}

Springer Nature remains neutral with regard to jurisdictional claims in published maps and institutional affiliations.

Received: 4 January 2017 Accepted: 22 May 2017

Published online: 05 June 2017

\section{References}

1. Rabeder G, Nagel D, Pacher M. Der Höhlenbär. Stuttgart: Thorbecke Verlag; 2000.

2. van Heteren AH, MacLarnon A, Soligo C, Rae TC. Functional morphology of the cave bear (Ursus spelaeus) mandible: a 3D geometric morphometric analysis. Org Divers Evol. 2016;16(1):299-314.

3. Knapp M, Rohland N, Weinstock J, Baryshnikov G, Sher A, Nagel D, et al. First DNA sequences from Asian cave bear fossils reveal deep divergences and complex phylogeographic patterns. Mol Ecol. 2009;18(6):1225-38.

4. Stuart AJ. Insularity and quaternary vertebrate faunas in Britain and Ireland. Geol Soc Spec Publ. 1995;96(1):111-25.

5. Garcia N, Arsuaga JL, Torres T. The carnivore remains from the Sima de los Huesos Middle Pleistocene site (sierra de Atapuerca, Spain). J Hum Evol. 1997;33(2):155-74

6. Barnosky AD, Koch PL, Feranec RS, Wing SL, Shabel AB. Assessing the causes of Late Pleistocene extinctions on the continents. Science. 2004;306(5693):70-5.

7. Stuart AJ. Late quaternary megafaunal extinctions on the continents: a short review. Geol J. 2015;50(3):338-63.

8. Stiller M, Baryshnikov G, Bocherens H, Grandal d'Anglade A, Hilpert B, Münzel SC, et al. Withering away - 25,000 years of genetic decline preceded cave bear extinction. Mol Biol Evol 2010;27(5):975-978.

9. Pacher M, Stuart AJ. Extinction chronology and palaeobiology of the cave bear (Ursus spelaeus). Boreas. 2009:38(2):189-206.

10. Baca M, Popović D, Stefaniak K, Marciszak A, Urbanowski M, Nadachowski A, et al. Retreat and extinction of the Late Pleistocene cave bear (Ursus spelaeus Sensu Lato). Sci Nat. 2016;103(11):92.

11. Krause J, Unger T, Noçon A, Malaspinas A-S, Kolokotronis S-O, Stiller M, et al. Mitochondrial genomes reveal an explosive radiation of extinct and extant bears near the Miocene-Pliocene boundary. BMC Evol Biol. 2008;8(1):1-12.

12. Bon C, Caudy N, de Dieuleveult M, Fosse P, Philippe M, Maksud F, et al. Deciphering the complete mitochondrial genome and phylogeny of the extinct cave bear in the Paleolithic painted cave of Chauvet. PNAS. 2008; 105(45):17447-52.

13. Loreille O, Orlando L, Patou-Mathis M, Philippe M, Taberlet P, Hanni C. Ancient DNA analysis reveals divergence of the cave bear, Ursus spelaeus, and brown bear, Ursus arctos, lineages. Curr Biol. 2001;11(3):200-3.

14. Ehrenberg K. Die Variabilität der Backenzähne beim Höhlenbären. In: Abel O, Kyrle G, editors. Die Drachenhöhle bei Mixnitz. Speläologische Monographien 7/8. Wien: Österreichische Staatsdruckerei; 1931. p. 537-573. 
15. Abel O. Das Lebensbild der eiszeitlichen Tierwelt der Drachenhöhle bei Mixnitz. In: Abel O, Kyrle G, editors. Die Drachenhöhle bei Mixnitz. Speläologische Monographien 7/8. Wien: Österreichische Staatsdruckerei; 1931. p. 885-920.

16. Kurtén B. The cave bear story. New York: Columbia University Press; 1976.

17. Kurtén B. Pleistocene mammals of Europe. Chicago: Aldine; 1968.

18. Thenius E. Zähne und Gebiß der Säugetiere. Berlin: W. de Gruyter; 1989.

19. van Heteren AH, MacLarnon A, Soligo C, Rae TC. Functional morphology of the cave bear (Ursus spelaeus) cranium: a three-dimensional geometric morphometric analysis. Quat Int. 2014;339:209-16.

20. Naito YI, Germonpré M, Chikaraishi Y, Ohkouchi N, Drucker DG, Hobson KA, et al. Evidence for herbivorous cave bears (Ursus spelaeus) in Goyet cave, Belgium: implications for palaeodietary reconstruction of fossil bears using amino acid 815N approaches. J Quat Sci. 2016;31(6):598-606.

21. Münzel SC, Rivals F, Pacher M, Döppes D, Rabeder G, Conard NJ, et al. Behavioural ecology of Late Pleistocene bears (Ursus spelaeus, Ursus ingressus): Insight from stable isotopes (C, N, O) and tooth microwear. Quat Int. 2014;339-340:148-63.

22. Bocherens $H$, Stiller M, Hobson KA, Pacher M, Rabeder G, Burns JA, et al. Niche partitioning between two sympatric genetically distinct cave bears (Ursus spelaeus and Ursus ingressus) and brown bear (Ursus arctos) from Austria: isotopic evidence from fossil bones. Quat Int. 2011:245(2):238-48.

23. Bocherens H, Drucker DG, Billiou D, Geneste J-M, van der Plicht J. Bears and humans in Chauvet cave (Vallon-Pont-d'Arc, Ardèche, France): insights from stable isotopes and radiocarbon dating of bone collagen. J Hum Evol. 2006;50(3):370-6.

24. Bocherens $H$, Billiou D, Patou-Mathis M, Bonjean D, Otte M, Mariotti A. Paleobiological implications of the isotopic signatures (13C,15N) of fossil mammal collagen in Scladina cave (Sclayn, Belgium). Quat Res. 1997;48(3):370-80.

25. Bocherens H, Fizet M, Mariotti A. Diet, physiology and ecology of fossil mammals as inferred from stable carbon and nitrogen isotope biogeochemistry: implications for Pleistocene bears. Palaeogeogr Palaeoclimatol Palaeoecol. 1994;107(3):213-25.

26. Richards MP, Pacher M, Stiller M, Quilès J, Hofreiter M, Constantin S, et al. Isotopic evidence for omnivory among European cave bears: Late Pleistocene Ursus spelaeus from the Peştera cu Oase, Romania. PNAS. 2008;105(2):600-4

27. Robu M, Fortin JK, Richards MP, Schwartz CC, Wynn JG, Robbins CT, et al. Isotopic evidence for dietary flexibility among European Late Pleistocene cave bears (Ursus spelaeus). Can J Zool. 2013;91(4):227-34.

28. Meloro C. Feeding habits of Plio-Pleistocene large carnivores as revealed by the mandibular geometry. J Vert Paleontol. 2011;31(2):428-46.

29. Figueirido B, Palmqvist P, Pérez-Claros JA. Ecomorphological correlates of craniodental variation in bears and paleobiological implications for extinct taxa: an approach based on geometric morphometrics. J Zool. 2009;277(1):70-80.

30. Jones BD, DeSantis LRG. Dietary ecology of the extinct cave bear: evidence of omnivory as inferred from dental microwear textures. Acta Palaeontol Pol. 2016;61(4):735-41.

31. Peigné S, Goillot C, Germonpré M, Blondel C, Bignon O, Merceron G. Predormancy omnivory in European cave bears evidenced by a dental microwear analysis of Ursus spelaeus from Goyet, Belgium. PNAS. 2009; 106(36):15390-3.

32. Rabal-Garcés R, Cuenca-Bescós G, Ignacio Canudo J, De Torres T. Was the European cave bear an occasional scavenger? Lethaia. 2012:45(1):96-108.

33. Bocherens $\mathrm{H}$. Isotopic tracking of large carnivore palaeoecology in the mammoth steppe. Quat Sci Rev. 2015:117:42-71.

34. Edinger T. Über einige fossile Gehirne. Paläont Z. 1928;9(4):379-402.

35. Über DH. Hirnschädelausgüsse von Ursus spelaeus. In: Abel O, Kyrle G, editors. Die Drachenhöhle bei Mixnitz. Speläologische Monographien 7/8. Wien: Österreichische Staatsdruckerei; 1931. p. 498-536.

36. Marinelli W. Bericht über die Untersuchung der Höhlenbärenschädel. In: Abel O, Kyrle G, editors. Die Drachenhöhle bei Mixnitz. Speläologische Monographien 7/8. Wien: Österreichische Staatsdruckerei; 1931 p. 332-497.

37. Finarelli JA, Flynn JJ. Brain-size evolution and sociality in Carnivora. PNAS 2009;106(23):9345-9.

38. Finarelli JA, Flynn JJ. The evolution of encephalization in caniform carnivorans. Evolution. 2007;61(7):1758-72.

39. Groiss JT. Untersuchungen der Gehirnmorphologie von Ursus deningeri v. REICHENAU und von Ursus spelaeus ROSENMÜLLER (Mammalia, Ursidae) an Schädelausgüssen quartärer Funde aus österreichischen Höhlen. Abh Geol B-A. 1994;50:115-23.

40. Santos E, Garcia N, Carretero JM, Arsuaga JL, Tsoukala E. Endocranial traits of the Sima de los Huesos (Atapuerca, Spain) and Petralona (Chalkidiki, Greece)
Middle Pleistocene ursids. Phylogenetic and biochronological implications. Ann Paleontol. 2014;100(4):297-309.

41. García N, Santos E, Arsuaga JL, Carretero JM. Endocranial morphology of the Ursus deningeri von Reichenau 1904 from the Sima de los Huesos (sierra de Atapuerca) Middle Pleistocene site. J Vert Paleontol. 2007;27(4):1007-17.

42. Smaers JB, Dechmann DKN, Goswami A, Soligo C, Safi K. Comparative analyses of evolutionary rates reveal different pathways to encephalization in bats, carnivorans, and primates. PNAS. 2012;109(44):18006-11.

43. Isler K, van Schaik CP. The expensive brain: a framework for explaining evolutionary changes in brain size. J Hum Evol. 2009;57(4):392-400.

44. Mink JW, Blumenschine RJ, Adams DB. Ratio of central nervous system to body metabolism in vertebrates: its constancy and functional basis. Am J Physiol Regul Integr Comp Physiol. 1981;241(3):R203-R12.

45. Aiello LC, Bates N, Joffe T. In defense of the expensive tissue hypothesis. In: Falk D, Gibson KR, editors. Evolutionary Anatomy of the primate Cerebral Cortex. Cambridge: Cambridge University Press; 2001. p. 57-78.

46. Dunbar RIM. The social brain hypothesis. Evol Anthropol. 1998:6(5):178-90.

47. Pérez-Barbería FJ, Shultz S, Dunbar RIM, Janis C. Evidence for coevolution of sociality and relative brain size in three orders of mammals. Evolution. 2007; 61(12):2811-21.

48. Shultz S, Dunbar RIM. Both social and ecological factors predict ungulate brain size. Proc Biol Sci. 2006;273(1583):207-15

49. Taylor AB, van Schaik CP. Variation in brain size and ecology in Pongo. J Hum Evol. 2007;52(1):59-71.

50. van Woerden JT, van Schaik CP, Isler K. Effects of seasonality on brain size evolution: evidence from strepsirrhine primates. Am Nat. 2010; 176(6):758-67.

51. van Woerden $\pi$, Willems EP, van Schaik CP, Isler K. Large brains buffer energetic effects of seasonal habitats in Catarrhine primates. Evolution. 2012;66(1):191-9.

52. Weisbecker V, Blomberg S, Goldizen AW, Brown M, Fisher D. The evolution of relative brain size in marsupials is energetically constrained but not driven by behavioral complexity. Brain Behav Evol. 2015;85(2):125-35.

53. Garamszegi LZ, Møller AP, Erritzøe J. Coevolving avian eye size and brain size in relation to prey capture and nocturnality. Proc Biol Sci. 2002; 269(1494):961-7.

54. Gittleman JL. Carnivore brain size, behavioral ecology, and phylogeny. J Mammal. 1986;67(1):23-36

55. Mace GM, Harvey PH, Clutton-Brock TH. Brain size and ecology in small mammals. J Zool. 1981;193(3):333-54.

56. Eisenberg JF, Wilson DE. Relative brain size and feeding strategies in the Chiroptera. Evolution. 1978;32(4):740-51.

57. Finarelli JA. Does encephalization correlate with life history or metabolic rate in Carnivora? Biol Lett. 2010:6(3):350-3.

58. Raichlen DA, Gordon AD. Relationship between exercise capacity and brain size in mammals. PLoS One. 2011:6(6):e20601.

59. Eisenberg JF, Wilson DE. Relative brain size and demographic strategies in didelphid marsupials. Am Nat. 1981;118(1):1-15.

60. Navarrete A, van Schaik CP, Isler K. Energetics and the evolution of human brain size. Nature. 2011:480(7375):91-3.

61. Barton RA, Capellini I. Maternal investment, life histories, and the costs of brain growth in mammals. PNAS. 2011;108(15):6169-74.

62. Isler K, van Schaik CP. Metabolic costs of brain size evolution. Biol Lett. 2006; 2(4):557-60

63. Weisbecker V, Goswami A. Brain size, life history, and metabolism at the marsupial/placental dichotomy. PNAS. 2010;107(37):16216-21.

64. Barrickman NL, Bastian ML, Isler K, van Schaik CP. Life history costs and benefits of encephalization: a comparative test using data from long-term studies of primates in the wild. J Hum Evol. 2008;54(5):568-90.

65. Western D. Size, life history and ecology in mammals. Afr J Ecol. 1979;17(4): 185-204.

66. Heldstab SA, van Schaik CP, Isler K. Being fat and smart: a comparative analysis of the fat-brain trade-off in mammals. J Hum Evol. 2016;100:25-34

67. Striedter GF. Principles of brain evolution. Sunderland: Sinauer Associates; 2005

68. DeCasien AR, Williams SA, Higham JP. Primate brain size is predicted by diet but not sociality. Nat Ecol Evol. 2017;1:0112

69. Hunter L. Carnivores of the world. Princeton (New Jersey): Princeton University Press; 2011.

70. Lyman CP, Willis JS, Malan A, Wang LCH. Hibernation and torpor in mammals and birds. New York: Academic Press; 1982.

71. Logan CJ, Clutton-Brock TH. Validating methods for estimating endocranial volume in individual red deer (Cervus elaphus). Behav Process. 2013;92:143-6. 
72. van Valkenburgh B. Skeletal and dental predictors of body mass in carnivores. In: Damuth J, Macfadden BJ, editors. Body size in mammalian paleobiology: estimation and biological implications. Cambridge: Cambridge University Press; 1990. p. 181-206.

73. Ebinger P. A cytarquitectonic volumetric comparison of brains in wild and domestic sheep. Z Anat Entwickl-Gesch. 1974;144:267-302.

74. Finarelli JA. Estimation of endocranial volume through the use of external skull measures in the Carnivora (Mammalia). J Mammal. 2006;87(5):1027-36.

75. R Development Core Team. R: A language and environment for statistical computing. Version 3.2.3. 2015. http://www.R-project.org. Accessed 10 Dec 2015.

76. Paradis E, Claude J, Strimmer K. APE: analyses of phylogenetics and evolution in R language. Bioinformatics. 2004;20:289-90.

77. Orme D, Freckleton R, Thomas G, Petzoldt T, Fritz S, Isaac N, et al. caper: comparative analyses of phylogenetics and evolution in R. R package version 0.5.2. 2013. https://CRAN.R-project.org/package=caper. Accessed 25 Jan 2016.

78. Kutschera VE, Bidon T, Hailer F, Rodi JL, Fain SR, Janke A. Bears in a forest of gene trees: Phylogenetic inference is complicated by incomplete lineage sorting and gene flow. Mol Biol Evol. 2014;31(8):2004-17.

79. Noonan JP, Hofreiter M, Smith D, Priest JR, Rohland N, Rabeder G. Genomic sequencing of Pleistocene cave bears. Science. 2005;309(5734):597-9.

80. Rabeder G, Hofreiter M. Der neue Stammbaum der alpinen Höhlenbären. Die Höhle. 2004:55:58-77.

81. Rabeder G, Hofreiter M, Nagel D, Withalm G. New taxa of Alpine cave bears (Ursidae, Carnivora). Cah Sci. 2004;2:49-67.

82. Rabeder G, Debeljak I, Hofreiter M, Withalm G. Morphological responses of cave bears (Ursus spelaeus group) to high-alpine habitats. Die Höhle. 2008; 59:59-72.

83. Dabney J, Knapp M, Glocke I, Gansauge M-T, Weihmann A, Nickel B, et al. Complete mitochondrial genome sequence of a Middle Pleistocene cave bear reconstructed from ultrashort DNA fragments. PNAS. 2013;110(39): 15758-63.

84. Baca M, Mackiewicz P, Stankovic A, Popović D, Stefaniak K, Czarnogórska K, et al. Ancient DNA and dating of cave bear remains from Niedźwiedzia Cave suggest early appearance of Ursus ingressus in Sudetes. Quat Int. 2014; 339-340:217-23.

85. Stiller M, Molak M, Prost S, Rabeder G, Baryshnikov G, Rosendahl W, et al. Mitochondrial DNA diversity and evolution of the Pleistocene cave bear complex. Quat Int. 2014;339-340:224-31.

86. Nyakatura K, Bininda-Emonds OR. Updating the evolutionary history of Carnivora (Mammalia): a new species-level supertree complete with divergence time estimates. BMC Biol. 2012;10(1):1-31.

87. Giraudoux P. pgirmess: data analysis in ecology. R package version 1.6.3. 2015. https://CRAN.R-project.org/package=pgirmess. Accessed 22 Jan 2016.

88. Pohlert $\mathrm{G}$. The pairwise multiple comparison of mean ranks package (PMCMR). 2014. http://CRAN.R-project.org/package=PMCMR. Accessed 22 Jan 2016.

89. Wickham H. ggplot2: elegant graphics for data analysis. New York: SpringerVerlag; 2009.

90. Maddison WP. Squared-change parsimony reconstructions of ancestral states for continuous-valued characters on a phylogenetic tree. Syst Zool. 1991;40(3):304-14.

91. Germain D, Laurin M. Evolution of ossification sequences in salamanders and urodele origins assessed through event-pairing and new methods. Evol Dev. 2009;11(2):170-90.

92. Maddison WP, Maddison DR. Mesquite: a modular system for evolutionary analysis. Version 2.75. 2011. http://mesquiteproject.org. Accessed 10 Dec 2014.

93. McLeod Al. Kendall: Kendall rank correlation and Mann-Kendall trend test. R package version 2.2. 2011. https://CRAN.R-project.org/package=Kendall. Accessed 9 May 2016.

94. Kaskan PM, Finlay BL. Encephalization and its developmental structure: how many ways can a brain get big? In: Falk D, Gibson KR, editors. Evolutionary Anatomy of the primate Cerebral Cortex. Cambridge: Cambridge University Press; 2001. p. 14-29.

95. Gibson KR, Rumbaugh D, Beran M. Bigger is better: primate brain size in relationship to cognition. In: Falk D, Gibson KR, editors. Evolutionary Anatomy of the primate Cerebral Cortex. Cambridge: Cambridge University Press; 2001. p. 79-97.

96. Hofman MA. Evolution of the human brain: when bigger is better. Front Neuroanat. 2014:8:15.
97. Roth G, Dicke U. Evolution of the brain and intelligence. Trends Cogn Sci. 2005;9(5):250-7.

98. Jerison HJ. Evolution of the brain and intelligence. New York: Academic Press; 1973

99. Yao L, Brown JP, Stampanoni M, Marone F, Isler K, Martin RD. Evolutionary change in the brain size of bats. Brain Behav Evol. 2012;80(1):15-25.

100. Edmunds NB, Laberge F, McCann KS. A role for brain size and cognition in food webs. Ecol Lett. 2016;19(8):948-55.

101. Lefebvre $L$, Whittle $P$, Lascaris $E$, Finkelstein A. Feeding innovations and forebrain size in birds. Anim Behav. 1997;53(3):549-60.

102. Ratcliffe JM, Fenton MB, Shettleworth SJ. Behavioral flexibility positively correlated with relative brain volume in predatory bats. Brain Behav Evol. 2006;67(3):165-76.

103. Reader SM, Laland KN. Social intelligence, innovation, and enhanced brain size in primates. PNAS. 2002;99(7):4436-41.

104. Lefebvre L, Reader SM, Sol D. Brains, innovations and evolution in birds and primates. Brain Behav Evol. 2004;63(4):233-46.

105. Weisbecker V, Goswami A. Reassessing the relationship between brain size, life history, and metabolism at the marsupial/placental dichotomy. Zool Sci. 2014;31(9):608-12

106. Safi K, Seid MA, Dechmann DKN. Bigger is not always better: when brains get smaller. Biol Lett. 2005;1(3):283-6.

107. Köhler M, Moyà-Solà S. Reduction of brain and sense organs in the fossil insular bovid Myotragus. Brain Behav Evol. 2004;63(3):125-40.

108. Weston EM, Lister AM. Insular dwarfism in hippos and a model for brain size reduction in Homo floresiensis. Nature. 2009:459(7243):85-8.

109. Sol D. Revisiting the cognitive buffer hypothesis for the evolution of large brains. Biol Lett. 2009;5(1):130-3.

110. Tacutu R, Craig T, Budovsky A, Wuttke D, Lehmann G, Taranukha D, et al. Human ageing genomic resources: integrated databases and tools for the biology and genetics of ageing. Nucleic Acids Res. 2013;41(D1):D1027-D33.

111. Ehrenberg K. Ein fast vollständiges Höhlenbärenneonatenskelett aus der Salzofenhöhle im Toten Gebirge. Ann Nathist Mus Wien. 1973;77:69-113.

112. Stiner MC. Mortality analysis of Pleistocene bears and its paleoanthropological relevance. J Hum Evol. 1998;34(3):303-26.

113. Radinsky L. Evolution of brain size in carnivores and ungulates. Am Nat. 1978:112(987):815-31.

114. Soul LC, Benson RBJ, Weisbecker V. Multiple regression modeling for estimating endocranial volume in extinct Mammalia. Paleobiology. 2012; 39(1):149-62.

115. Christiansen P. What size were Arctodus simus and Ursus spelaeus (Carnivora: Ursidae)? Ann Zool Fenn. 1999:36(2):93-102

\section{Submit your next manuscript to BioMed Central and we will help you at every step:}

- We accept pre-submission inquiries

- Our selector tool helps you to find the most relevant journal

- We provide round the clock customer support

- Convenient online submission

- Thorough peer review

- Inclusion in PubMed and all major indexing services

- Maximum visibility for your research

Submit your manuscript at www.biomedcentral.com/submit
) Biomed Central 